Research Article

\title{
Multimodal IT marketing discourse: An integrated approach investigation
}

\author{
Natalia Sokolova \\ Perm National Research Polytechnic University \\ Perm, Russia
}

\begin{abstract}
Websites of software vendors feature verbal and nonverbal means providing for a number of parameters to be taken into account in order to gain more comprehensive insights into the range and interplay of the means in use. This paper investigates the multimodal website marketing discourse of Microsoft, Oracle, and SAP relying on an approach which makes use of multimodal critical discourse analysis, pragmatics, and text linguistics. The integrated framework allows for consideration of the discourse-generating intention of the locutionary source, the discourse function, verbal content categories and audio-visual techniques employed in the nonverbal discourse contributing to the global category of ideologeme consisting of key ideas and aimed at the locutionary target. The intention of such discourse is to persuade consumers to purchase IT solutions which is manifested in the persuasive function. The textual content has been investigated in terms of a set of categories such as: the theme, including IT terms; tonality, made explicit through positively charged words and imperative sentences; time and space, emphasizing time saving efforts to deal with challenges enterprise-wide. The findings are similar to those revealed in the verbal content of customer testimonial videos, with audio-visual techniques such as invigorating music, company settings, contrast colors, etc. being alike. It is of particular interest that the linguistic means in these three marketing discourses are different only when it comes to metaphorical expressions. The global ideologeme is made explicit by urging customers to optimize data and feel IT-powered performance benefits. It is conveyed through multiple antitheses such as data challenges vs. one solution, previously vs. now, old vs. new, and slowly vs. fast. The antitheses in the three marketing discourses are similar as are the typical manifestations of categories and audio-visual techniques which may encourage further research in terms of making the specific discourse of a company stand out to its customers.
\end{abstract}

Keywords: marketing discourse, information technology, intention, persuasion, category, ideologeme

For citation:

Sokolova, Natalia. 2020. Multimodal IT marketing discourse: An integrated approach investigation. Russian Journal of Linguistics 24 (2). 366-385. DOI: 10.22363/2687-00882020-24-2-366-385 
Научная статья

\title{
Мультимодальный маркетинговый дискурс сферы информационных технологий: интегративный подход к анализу
}

\author{
Н.В. Соколова \\ Пермский национальный исследовательский политехнический университет \\ Пермь, Россия
}

\begin{abstract}
Аннотация
На веб-сайтах компаний сферы информационных технологий представлены вербальные и невербальные средства, что требует учета ряда параметров в ходе анализа для получения более полного представления о спектре и взаимодействии данных средств. В работе проводится интегративный анализ мультимодального маркетингового дискурса веб-страниц производителей программного обеспечения Microsoft, Oracle и SAP с учетом положений мультимодального критического дискурс-анализа, прагматики, а также лингвистики текста. Полагаем, что целесообразным является учет следующих параметров: дискурсопорождающая интенция адресанта, функция дискурса, реализация категорий в вербальном контенте мультимодального дискурса и использование аудиовизуальных приемов в невербальном контенте, глобальная идеологема, или ключевая идея дискурса, а также адресат. Дискурсопорождающей интенцией является побуждение потребителя к приобретению ИТ-решения, при этом дискурс реализует воздействующую функцию. Текстовое наполнение веб-сайтов рассматривается в рамках таких категорий, как тема (терминология сферы информационных технологий); тональность (положительно окрашенная лексика; повелительное наклонение); хронотоп (экономия времени для решения глобальных задач в рамках всего предприятия). Проведенный анализ позволил получить аналогичные результаты в отношении категорий на материале вербального наполнения видеоотзывов клиентов, при этом аудиовизуальные приемы в виде использования динамичной музыки, видов компании, контрастных цветов и пр. сходны. Примечательно, что использование различных лингвистических средств было выявлено лишь в ходе анализа метафорических выражений, представленных в маркетинговых дискурсах трех компаний. Глобальной идеологемой маркетинговых дискурсов является призыв к реципиенту оптимизировать управление данными для обеспечения эффективного развития в ближайшем будущем. Приемом реализации типичной идеологемы становятся многократно используемые антитезы: проблемы работы с большим количеством данных vs. одно ИТ-решение, ситуация до и после, старое vs. новое, медленно vs. быстро. Анализ показывает, что в рамках маркетинговых дискурсов трех компаний используются сходные антитезы, а реализация категорий и аудиовизуальных приемов также аналогична, что может потребовать дальнейших исследований маркетингового дискурса с точки зрения восприятия его специфичности клиентами.
\end{abstract}

Ключевые слова: маркетинговый дискурс, информационные технологии, интенция, убеждение, категория, идеологема

\section{Для цитирования:}

Sokolova, Natalia. 2020. Multimodal IT marketing discourse: An integrated approach investigation. Russian Journal of Linguistics 24 (2). 366-385. DOI: 10.22363/2687-00882020-24-2-366-385 


\section{Introduction}

Nowadays, enterprise websites are instrumental in paving the way for projecting ideas to customers. The webpages of such websites feature verbal, or textual, information about the benefits of products and services envisaged to meet customers' needs. Nonverbal content, that is nonlinguistic information transmitted through visual and auditory channels, is also an integral part of the websites: users can enjoy background colors, browse through photos, and play customer testimonial videos providing insights into the benefits of products.

Both the verbal and nonverbal audio-visual content makes up the website discourse which needs to be investigated through integrated approaches due to its heterogeneous components aimed at producing some synergetic impact. Contemporary linguistic studies demonstrate an ongoing search for new integrated ways taking into account a number of parameters to deliver comprehensive insights into the material under study (Abbamonte, Cavaliere 2017; Klushina 2012; Klushina 2016; Kress 2010; Mooney 2019). This paper attempts to identify an integrated approach to investigating the verbal and nonverbal discourse of software vendors' websites.

\section{Multimodal critical discourse, pragmatics, and text linguistics}

First of all, the notions of text and discourse must be differentiated. Discourse can be described as the broadest term for describing all the forms of using language (Kibrik 2009: 1). There exists a definition we consider to be making the most of the existing ideas about discourses intrinsically connected to and associated with some spheres of life (Fairclough 2000), with discourses being identified as collections of texts having some key parameter in common that may be made explicit through adjectives such as, 'Crimean discourse', 'theatrical discourse', etc. (Klushina 2016: 82). The idea of the interaction between discourse and social life was particularly emphasized by N. Fairclough: "The term discourse (in what is widely called 'discourse analysis') signals the particular view of language in use I have referred to above - as an element of social life which is closely interconnected with other elements" (Fairclough 2000: 3). Various types of discourses can be in the research spotlight such as the discourse of luxury brands (Adebeshin 2015), tourism (Caruana 2011), consumers (Roper, Caruana, Medway, Murphy 2013), etc.

This paper deals with information technology discourse reaching out to customers through the websites of Microsoft, Oracle, and SAP. Since the websites under study feature not only texts but also nonverbal content such as videos (as demonstrated in Figure 1 below), this discourse is definitely a multimodal one (Kress 2010; Van Leeuwen 2013), with visual semiotics being intrinsic to it (Van Leeuwen, 2013) while the meaning results from the use of all the means (Lemke 1998).

The discourse under study is obviously part of computer-mediated communication (Shchipitsyna 2009) being a multimedia one (Opgenhaffen 2001). 


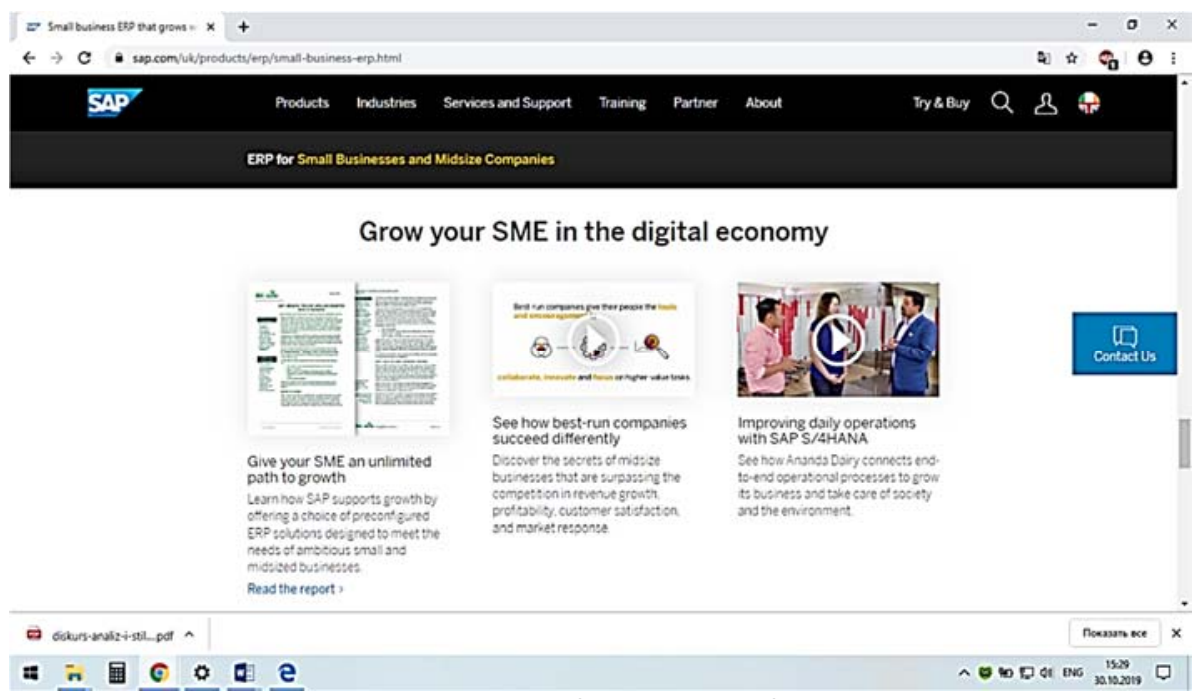

Fig. 1. SAP webpage screenshot

The next point to be clarified within the methodology section of this paper regards the notions of advertising and marketing discourses. The so-called language of advertising has been in the spotlight for quite a long time (Pirogova, Parshin 2000; Dyer 1988). However, according to E.G. Borisova, today we can speak of marketing linguistics as a particular area of study dealing with 'marketing discourse' made of advertising slogans, texts, promotion speeches, brand names, verbal components of logos and so on (Borisova 2016; see also Borisova, Vikulova et al. 2019) and differentiated from other discourses based on the type of social activity. That is, marketing activity is aimed at "creating, communicating, delivering, and exchanging offerings that have value for customers, clients, partners, and society at large" 1 in some specific sector so we can speak of tourism marketing discourse, health marketing discourse, etc. (Caruana and Fitchett 2015), real estate marketing discourse (Savelyeva 2015), etc. and - as in this case-IT marketing discourse. Marketing discourse per se is an all-encompassing phenomenon as compared to advertising discourse. Similarly, a carefully elaborated marketing activity consists of advertising campaigns and not the other way around.

The idea of a multimodal marketing discourse of IT translated through the corporate websites under study also goes well with the fact that the websites demonstrate the results of implementing some other marketing activity involving case studies, blogs, expert reviews, infographics, customer testimonials, videos, photos, etc. Critical discourse analysis unraveling central ideas expressed in the discourse is also instrumental in this respect since it has moved towards including multimodal means into analysis (Kress 2010) showing how graphics also work together to augment meanings communicated through texts.

1 American Marketing Association [Electronic resource]. URL: https://www.ama.org/ the-definition-of-marketing-what-is-marketing/ (accessed 02.11.2019). 
Since marketing discourse and the company-customer communication are intrinsic, pragmatic issues come to the foreground involving both the source and the target of the communicative process.

One of the proven integrated approaches has been elaborated by N.I. Klushina on the material of the publicistic discourse. The so-called 'intentional method' provides an outline of the following communicative process: locutive source intention - text + communicative situation - locutive target - decoding impact (perlocution) (Klushina 2012) taking into account communicative, pragmatic, and semiotic aspects and demonstrating an undeniable explanatory potential.

So it is of primary importance in my opinion to begin with the pragmatic issues involving the locutionary source since the starting point of generating any discourse is the intention (Klushina 2012) of the locutive source which yields some function (Kozhina 2006: 576) to the generated outcome and finds manifestation in the global category of ideologeme (Klushina 2012) and other categories constituting this or that discourse. The intentional method (Klushina 2012) provides for analyzing discourses through identifying the discourse-related category of the ideologeme which is defined as the key ideas to be conveyed through the discourse activity (Klushina 2012).

Texts and the textual content of videos can be also investigated within the framework of other categories of text linguistics such as theme, or the matter under discussion (Matveeva 2006: 542-544), tonality, demonstrating the source's attitude (Matveeva 2006b: 549-552), time and space, as well as the composition, or the structure, which are intrinsic and essential features finding their linguistic manifestation in texts (Matveeva 2006c: 533-536). Since texts make up discourses, textual categories can be easily transposed and projected onto the entire marketing discourse and considered as discourse-related ones.

\section{Material and integrated methodology}

To apply the integrated methodology outlined above, the paper draws upon both the verbal and nonverbal website content of first-class software vendors such as Microsoft ${ }^{2 ; 3}$, racle $^{4 ; 5}$, and $S A P^{6 ; 7}$ in the amount of about 80,000 characters

${ }^{2}$ Microsoft [Electronic resource]. URL: https://www.microsoft.com/en-us/microsoft-365 (accessed 02.11.2019).

${ }^{3}$ Microsoft [Electronic resource]. URL: https://www.microsoft.com/en-us/microsoft-365/ business (accessed 02.11.2019).

4 Oracle [Electronic resource]. URL: https://www.oracle.com/index.html (accessed 02.11.2019).

${ }^{5}$ Oracle [Electronic resource]. URL: https://www.oracle.com/big-data/ (accessed 02.11.2019).

${ }^{6}$ SAP [Electronic resource]. URL: https://www.sap.com/index.html (accessed 02.11.2019).

7 SAP [Electronic resource]. URL: https://www.sap.com/uk/products/erp/small-businesserp.html; https://www.sap.com/products/erp/erp-cloud-exp-sme.html?adobe_mc_ref=https\%3A\% 2F\%2Fwww.google.ru\%2F\&adobe_mc_sdid=SDID\%3D71393FEA67F96A85-1227EC351509 D7EF\%7CMCORGID\%3D227AC2D754DCAB340A4C98C6\%2540AdobeOrg\%7CTS\%3D1532 250423\#video $=c 4496 f$ fe2-137d-0010-87a3-c30de2ffd8ff (accessed 02.11.2019). 
while relying on a number of proven methodologies elaborated in the fields of discourse studies (Klushina 2012; Klushina 2016), multimodal critical discourse analysis (Bateman 2014; Kress 2010; Kress and Van Leeuwen 2001) and visual semiotics (Van Leeuwen, 2013) as well as pragmatics of advertising (Popova 2005) and text linguistics (Kozhina 2006; Matveeva 2006a). The methodology perspective outlined in this paper provides for analyzing both the verbal and audiovisual components of the material under study such as images, colors, and testimonial videos.

So the integrated analysis framework proposed in this paper to investigate the multimodal marketing discourse of IT vendors' websites provides for identifying the locutionary source's intention as a discourse-generating component and an ideologeme - the key idea to be conveyed through the discourse activity (Klushina 2012) - as a global discourse-generating category.

The verbal content of the websites can be investigated through the use of textual categories such as composition, theme, tonality, time and space. These categories can also be instrumental in analyzing the verbal content of customer testimonial videos. Audio-visual techniques such as music, voice, and color are also taken into account to deal with the nonverbal content. The global ideologeme is realized throughout the entire discourse made of texts.

Since the ideologeme of marketing discourse is supposed to be appealing to existing and potential customers it can be also identified in terms of lines of appeal (Dyer 1988) - themes proven to appeal to the audience such as elite lifestyles, success stories, etc. (Dyer 1988). However, as compared to such lines of appeal, ideologemes seem to be a more appropriate term in our context because they tend to be more comprehensive, both negative and positive, while lines of appeal deal with specific good things such as success, health, etc.

Thus, the framework proposed in this paper to analyze multimodal marketing discourse of software vendors' websites provides for identifying:

- the intention (or illocution) of the locutionary source aimed at the locutionary target;

- the function of the discourse;

- the categories of the verbal, or textual, content such as composition, theme, tonality, time and space;

- the audio-visual techniques employed in the nonverbal content such as background colors and images, as well as voice, music, settings, and salience, or dominant images that draw attention, in videos;

— the global discourse category of ideologeme.

\section{Analysis and results}

The marketing discourse of the Microsoft, Oracle, and SAP websites under investigation is generated with the overall intention of persuading customers to purchase IT solutions. Hence, it is the persuasive function that is dominant in the discourse. 


\subsection{Verbal content}

First of all, it is necessary to focus on the categories which find manifestation in the verbal discourse. And this is when the discourse-generating category of intention should be considered as the key one. Hypertextual, interactive, and multimodal websites and webpages (Opgenhaffen 2011; Shchipitsina 2009) consist of multiple texts, videos, etc. having titles and subtitles of their own while users can browse through and choose some content (see Figure 1 above) so it is the global category of intention that brings all these constituent parts together.

The webpages under study have a typical composition and feature the title and some subtitles followed by texts providing insights into specific software benefits. The table below contains some titles and subtitles. These are mostly imperative sentences and can be explained by their dominant persuasive function. There are also nominative sentences to name the products and technologies in use and some interrogative sentences, with the answers to these questions supposed to emphasize the product benefits (Table 1):

Table 1

Webpage titles and subtitles

\begin{tabular}{|c|c|c|c|}
\hline $\begin{array}{c}\text { Software } \\
\text { vendor }\end{array}$ & Microsoft & Oracle & SAP \\
\hline Title & Microsoft 365 for business & $\begin{array}{c}\text { Why Big Data from } \\
\text { Oracle? }\end{array}$ & $\begin{array}{c}\text { Solve your specific ERP } \\
\text { small business needs }\end{array}$ \\
\hline Subtitles & $\begin{array}{c}\text { Everything you need, } \\
\text { everywhere you need it }\end{array}$ & $\begin{array}{c}\text { Elements of Successful Big } \\
\text { Data Platforms }\end{array}$ & $\begin{array}{c}\text { Take control with SME } \\
\text { ERP }\end{array}$ \\
\cline { 2 - 4 } & Don't drown in paperwork & Big Data Technologies & Meet cloud-based ERP \\
\cline { 2 - 4 } & Protect what matters most & See the Proof & Simplify life at work \\
\hline
\end{tabular}

The discourse-generating intention of persuading customers to make a purchase finds its manifestation in the categories of theme, tonality, time and space, with one of the most accurate natural language processing APIsTextRazor ${ }^{8}$ - being utilized in the study to extract examples of the categories.

The theme manifests itself through repetitive uses of words such as neutral IT terms application, software, data, cloud, etc. and related words customer, business, company, etc. The themes identified in the study are very similar for all the three software vendors: customer - business - productivity - application - data cloud - email for Microsoft; business — data - cloud - application for Oracle; and business - customers - cloud - solution for SAP.

The tonality of the material under analysis is generally positive, with the words such as easi(ly), quick(ly), rapid(ly), fast, etc. being repeatedly used in all the three discourses to emphasize the fact that customers can improve their performance in no time:

\footnotetext{
${ }^{8}$ TextRazor [Electronic resource]. URL: https://www.textrazor.com/ (accessed 02.11.2019).
} 
(1) Make repetitive tasks easy; Quickly and easily automate processes [Microsoft].

(2) Prepare and manage your data more easily; Combine your data more easily; And start analyzing it more easily to uncover insights you've never seen before; Utilizing big data allows organizations to make smarter and faster decisions using data and insights [Oracle].

(3) Maximise business agility with standardized processes, rapid innovation, and fast time-to-value [SAP].

The comparative and superlative forms of adjectives and adverbs are also typical: more easily, better, greater, etc. to focus on the positive change. In addition, words such as efficiently and effectively can be used in this way:

(4) Learn how Fissler uses an intelligent cloud ERP solution to efficiently implement new subsidiaries in strategic markets worldwide [SAP].

The terminology and theme-related words can be preceded by positive adjectives such as best-in-class productivity, intelligent new way, advanced, worldclass security [Microsoft]; smarter and faster decisions, true data discovery [Oracle]; ambitious businesses, profitable growth [SAP], etc.

All three discourses of the software vendors demonstrate the presence of popular marketing words which can be classified as lines of appeal to potential customers. A good example is the word insight(s) which denotes valuable, visionary information enhancing company performance:

(5) Create surveys, polls, and questionnaires to quickly gather data and insights with Microsoft Forms [Microsoft].

(6) And start analyzing it more easily to uncover insights you've never seen before - with true data discovery [Oracle].

(7) Use it to streamline processes from finance to CRM, act on real-time analytics insights - and jump on new opportunities; gain greater insight into your business, and make decisions based on real-time information-so you can drive profitable growth [SAP].

The marketing discourse is abundant in imperative sentences starting with positively charged verbs such as streamline, enhance, improve, innovate, etc. encouraging and persuading customers to try the IT products:

(8) Improve productivity and foster a culture of collaboration; Enhance customer relationships; Stay up to date with the latest versions; Streamline customer feedback; Defend against malware [Microsoft].

(9) Maximize efficiency and increase revenue; Discover the top big data use cases [Oracle].

(10) Solve your specific ERP small business needs; Gain greater control over your SME with small business management software and ERP tools designed to grow with you; Innovate and transform at the speed of digital; Streamline key processes [SAP]. 
It is of particular interest that the theme-related and positively charged words are similar in all the three discourses of Microsoft, Oracle, and SAP, with words such as easi(ly), quick(ly), efficient(ly), great, data, insight, streamline, etc. being repeatedly used. This can make it really challenging for customers to differentiate between the discourses of the three companies and-respectively-to choose a solution among some counterparts. For example, verbs such as transform, enhance, streamline, etc. [Microsoft]; enhance, improve, leverage, etc. [Oracle]; improve, innovate, transform, streamline, etc. [SAP] tend to be used by all three vendors.

At the same time, the discourses under study make very specific use of positively charged metaphors to emphasize the benefits of their IT solutions:

(11) Don't drown in paperwork [Microsoft].

(12) Unlock new levels of performance across your organization; Jump onto new opportunities; Use automation and intelligent technologies to break new ground [SAP].

(13) Only Oracle delivers a data management platform that absorbs and delivers data of any size and shape for any type of application: analytics or algorithm, across any type of environment: public cloud, local cloud, or onpremises; ERP software is the backbone of many organizations [Oracle].

Thus, theme and tonality find their manifestation in the Microsoft, Oracle, and $S A P$ discourses through a similar use of IT-related terms and popular marketing words, positive adjectives and adverbs being part of imperative sentences urging customers to benefit from the IT solutions. It is also due to a specific use of metaphors that the discourses of the three vendors get their specific appeal.

Time and space categories are also closely intertwined in the discourses under investigation. The present days are described as a time of dealing with massive amounts of data:

(14) 22 Big Data Use Cases for the Modern Business; Data arrives from everywhere these days [Oracle].

This is when the solutions of the IT companies are supposed to come in handy to easily and quickly solve this problem so the idea of saving time due to optimizing data management is crucial in this respect.

As for the category of space, all the vendors under study focus on the feature of providing powerful all-encompassing enterprise-wide solutions within just a single software suite:

(15) Manage your files from anywhere with $1 T B$ of OneDrive storage [Microsoft].

(16) Only Oracle delivers a data management platform that absorbs and delivers data of any size and shape for any type of application: analytics or algorithm, across any type of environment: public cloud, local cloud, or onpremises; Bring all of the different types of data into your organization. Whether it's data at rest or data in motion, internal or external data, all of your data must be moved and prepared so that others can consume it [Oracle]. 
(17) Control your entire organisation with streamlined business processes and integrated business intelligence-all in one affordable, scalable ERP software solution; Transform your business with unparalleled service support enterprise-wide [SAP].

So the discourse manifestation of the time and space categories contributes to the locutionary targets of Microsoft, Oracle, and SAP the same idea of getting an all-encompassing solution to handle current data challenges enterprise-wide while the use of you and your is typical (Serrano 2018) in reaching out to potential customers.

Ultimately, the categories of composition, theme and tonality, time and space work together to deliver the global ideologeme, or the central idea, of the marketing discourse under study. This ideologeme of IT-powered efficient performance is made explicit by urging the locutive targets to quickly optimize data management through the use of a single efficient solution for managing all company data to feel the benefits of enhanced performance as soon as possible.

This typical ideologeme is conveyed to the locutionary target through sophisticated antitheses, or juxtapositions (Roper, Caruana, Medway, Murphy 2013), embedded in the marketing discourse for persuading the recipients to experience the benefits of the IT solutions.

The analysis of the $S A P$, Microsoft, and Oracle webpages demonstrates the use of the following antitheses summarized with only a few of examples from above (Table 2):

Table 2

Antitheses of the marketing discourse

\begin{tabular}{|c|c|c|c|}
\hline & Microsoft & Oracle & SAP \\
\hline $\begin{array}{l}\text { Multiple data } \\
\text { challenges vs. a } \\
\text { single solution to } \\
\text { deal with all these } \\
\text { challenges in a } \\
\text { company }\end{array}$ & $\begin{array}{l}\text { Microsoft } 365 \text { integrates } \\
\text { with hundreds of third- } \\
\text { party cloud apps so you } \\
\text { can sign in once to } \\
\text { access all your tools; etc. }\end{array}$ & $\begin{array}{l}\text { Bring all of the } \\
\text { different types of } \\
\text { data into your } \\
\text { organization; etc. }\end{array}$ & $\begin{array}{l}\text { Capture all of your data } \\
\text { in an integrated } \\
\text { enterprise resource } \\
\text { planning (ERP) system } \\
\text { for small businesses and } \\
\text { midsize companies; etc. }\end{array}$ \\
\hline $\begin{array}{l}\text { Previously vs. } \\
\text { nowadays implying } \\
\text { old vs. new, } \\
\text { slowly vs. fast, } \\
\text { inefficiently vs. } \\
\text { efficiently }\end{array}$ & $\begin{array}{l}\text { Microsoft } 365 \text { brings } \\
\text { together the best-in- } \\
\text { class productivity of } \\
\text { Office } 365 \text { with simple } \\
\text { device management and } \\
\text { security to connect } \\
\text { people and information } \\
\text { in an intelligent new } \\
\text { way. Quickly and easily } \\
\text { automate processes } \\
\text { within your business } \\
\text { with Microsoft Flow; etc. }\end{array}$ & $\begin{array}{l}\text { Utilizing big data } \\
\text { allows organizations, } \\
\text { analysts, and line-of- } \\
\text { business users to } \\
\text { make smarter and } \\
\text { faster decisions using } \\
\text { data and insights that } \\
\text { were previously } \\
\text { unobtainable or } \\
\text { unknown; etc. }\end{array}$ & $\begin{array}{l}\text { Use it to streamline } \\
\text { processes from finance } \\
\text { to CRM, act on real-time } \\
\text { analytics insights-and } \\
\text { jump on new } \\
\text { opportunities; etc. }\end{array}$ \\
\hline
\end{tabular}

One more important part of the verbal content is customer testimony demonstrating the same manifestations of the data-related theme, positive tonality, 
business-focused time and space as well as the antitheses identified in the marketing discourse above.

The similar antitheses of multiple data vs. one solution and previously vs. now are repeated in the customer comments below, for example, while talking about using one solution to handle lots of data:

(18) Microsoft 365 Business is pretty much the baseline for how we start running everything. We need creativity to push that next thing. We use Microsoft 365 Business. It's all the things we need in one place [Microsoft]. (19) With Oracle Cloud, we automated our procurement and inventory processes on a single cloud platform with in-depth reporting on all commercial cement operations [Oracle].

It's also important for the customers to feel the difference between how it was before and how it is now:

(20) Microsoft 365 Business brings a new level of confidence and security we didn't have before [Microsoft].

(21) Oracle Advanced Customer Services optimized our deployment and their services ensure that we always have expertise to resolve any issue [Oracle].

Focusing on the before vs. now juxtaposition, the customers also emphasize the fact that they can do things faster and better:

(22) With Teams, we immediately felt the impact of having channels where you get a fast response because your question is relevant to that channel rather than something that could get lost in a giant group chat [Microsoft].

(23) Deloitte Mexico achieves faster time-to-market with Oracle Big Data Appliance. Clover Infotech. Oracle ERP helped Clover Infotech better manage their data and reporting, save time, and automate processes [Oracle]. (24) Find out how a cloud-based ERP system helps a growing candle business save time and boost operational efficiency while creating customised goods [SAP].

However, the composition of the customer testimony is different since it is a narration delivering such lines of appeal as success, security, etc. without any use of imperative sentences as compared to the imperative discourse of the vendors.

Thus, the imperative discourse, the IT theme, positive tonality, allencompassing time and space categories of the verbal content work together to deliver the juxtaposed prior vs. now positive ideologemes of the IT-powered efficient performance as the locutionary sources encourage their customers to feel the benefits of the IT solutions while the locutionary sources share their success stories focusing on their lines of appeal.

\subsection{Nonverbal, or audio-visual, content}

The IT marketing discourse under analysis is multimodal, with colors, images, and videos also playing their role.

The importance of using background contrast colors cannot be ignored: lines between the texts of $S A P$ (see Figure 1 above); the grey-and-white background of 
Microsoft (see Figure 2 below); contrasts in black, blue and white colors on the Oracle website (see Figure 3) help information stand out.

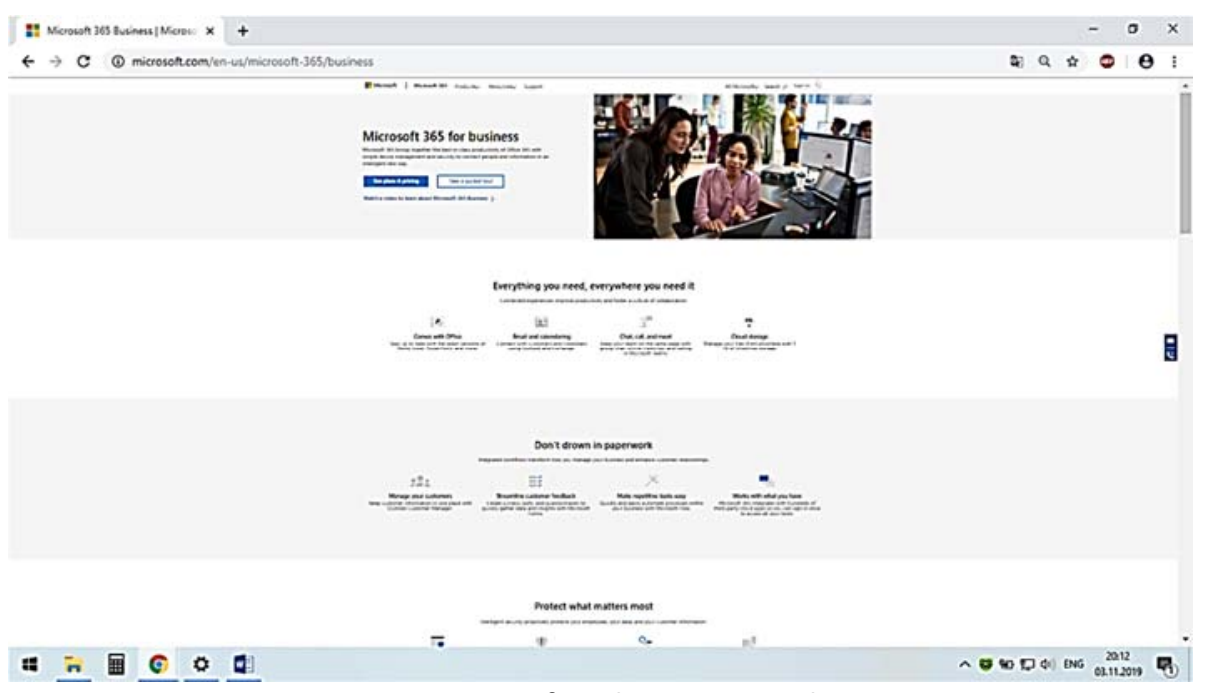

Fig. 2. Microsoft webpage screenshot

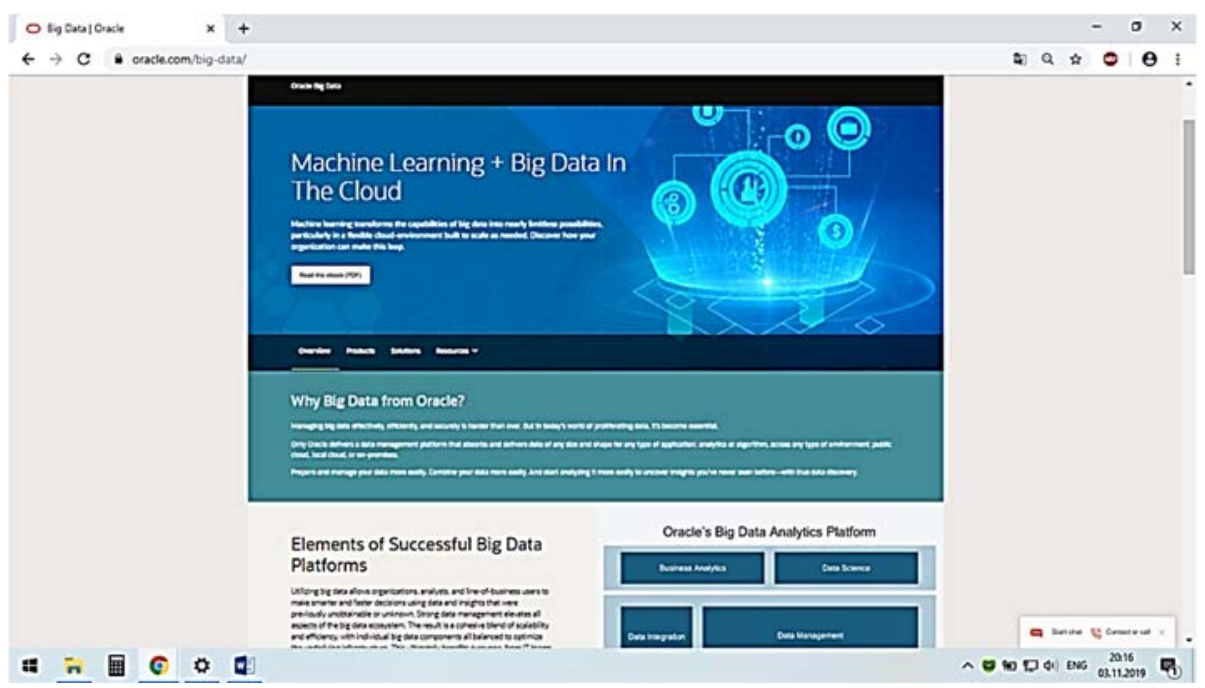

Fig. 3. Oracle webpage screenshot

The photos on the websites feature customers in the working settings (Figure 2 above). Customer testimonial videos can also be found on the websites under study making them part of the multimodal marketing discourse.

Nine customer testimonial videos will be analyzed below taking into account a number of parameters for investigating the verbal content such as speeches and nonverbal components including music, settings, and salience (the dominant image that draws our attention). The following parameters seem to be the most relevant in our case: composition, antithesis, theme, tonality, time and space, audio techniques (voice and music), visual techniques (salience and setting), and ideologemes. 
As mentioned before, the ideologeme of the locutionary source is made explicit by urging the locutive targets to quickly optimize data management through the use of one efficient solution to manage all company data and to feel the benefits of enhanced performance as soon as possible. Via the customer testimonial videos, this ideologeme transforms into some experience of a particular company focusing more on lines of appeal such as success, security, etc. while this transformation has also been identified earlier in the customer testimony texts.

Generally, the textual content of the customer testimonial videos is a narrative providing some information about the successful implementation of the vendors' solutions similarly to the customer testimony texts. The composition of the customer testimonial videos analyzed relies on the typical antithesis of the situation prior and after implementing the solutions.

All the videos of Microsoft, Oracle, and SAP under study have a similar composition:

1) Company information: providing some information about the company, including facts and figures; with;

2) Challenges: focusing on the challenges the business had to face and cope

3) Solutions and benefits: commenting on how the acquired solutions have contributed to solving all the problems;

4) Future outlook: outlining future perspectives for the growing and evolving business.

Below are Tables 3, 4, and 5 providing the details of this analysis, with some changes being evident in the customer testimonial videos since the theme shifts from the IT terms to core values such as quality, innovation, saving, security, etc. while the tonality remains positive. The categories of time and space find a typical manifestation since the information is just about doing things faster on an enterprise-wide scale. As for the antitheses employed in the customer testimonial videos, they are generally related to the situation prior and after, however, the spokespeople tend to dwell into more detail such as non-customized vs. customized, old vs. new, worse vs. better, etc. Some audio-visual techniques are used in this case to make the content more persuasive through a synergy of verbal and nonverbal means, for example, invigorating music, scenes of the facilities, and top spokespeople enumerating the benefits gained.

Table 3 below outlines a summary of the Microsoft customer testimonial video analysis providing insights into the composition, antitheses, appealing themes, tonality, time, space, and audio-visual techniques, such as: music, voice, setting, and salience. The findings demonstrate that Microsoft customers tend to focus on such themes and lines of appeal as quality, security, integration, innovation, growth, etc. The composition is typical being centered around company spokespersons - both males and females - and evolving from the company details and settings through challenges to solutions creating the positive tonality of the resulting faster, better, right, rocketing, etc. performance backed up with 
invigorating music. Having been put together, the constituent elements contribute to creating an antithesis of the prior and current state of things, with the former being disintegrated and slow and the latter — consolidated and fast — due to a single efficient solution:

Table 3

Analysis of Microsoft customer testimonial videos

\begin{tabular}{|c|c|c|c|}
\hline Video & $\begin{array}{l}\text { Microsoft customer } \\
\text { testimonial video } 1^{9} \text {. Duration } \\
02: 13\end{array}$ & $\begin{array}{l}\text { Microsoft customer } \\
\text { testimonial video } 2^{10 .} \\
\text { Duration 02:03 }\end{array}$ & $\begin{array}{l}\text { Microsoft customer } \\
\text { testimonial video } 3^{11} . \\
\text { Duration } 01: 30\end{array}$ \\
\hline Company & UMBRAGROUP & Urban Agriculture Co. & Garner Food Company \\
\hline Composition & $\begin{array}{l}\text { 1) company information: five } \\
\text { world-wide units of a world- } \\
\text { leading provider for the space } \\
\text { and energy market } \\
\text { 2) challenges: reduce costs } \\
\text { and increase the security and } \\
\text { agility level } \\
\text { 3) solutions: they can share } \\
\text { KPIs across the company and } \\
\text { with their partners, make } \\
\text { decisions faster, scale } \\
\text { processes faster } \\
\text { 4) future outlook: they can } \\
\text { get better }\end{array}$ & $\begin{array}{l}\text { 1) company } \\
\text { information: operating in } \\
50 \text { states of the USA } \\
\text { 2) challenges: start } \\
\text { running the business } \\
\text { effectively } \\
\text { 3) solutions: improved } \\
\text { company performance } \\
\text { 4) future outlook: they } \\
\text { can grow further }\end{array}$ & $\begin{array}{l}\text { 1) company information: } \\
\text { a family business producing } \\
\text { tens of millions of sauce } \\
\text { bottles } \\
\text { 2) challenges: handling } \\
\text { lots of things } \\
\text { 3) solutions: better } \\
\text { company operation } \\
\text { 4) future outlook: they } \\
\text { can expand }\end{array}$ \\
\hline Antithesis & $\begin{array}{l}\text { prior: disintegrated and slow } \\
\text { now: consolidated and fast }\end{array}$ & $\begin{array}{l}\text { prior: disintegrated } \\
\text { now: consolidated }\end{array}$ & $\begin{array}{l}\text { prior: lots of things to } \\
\text { handle } \\
\text { now: one solution for } \\
\text { everything: it's all the things } \\
\text { that we need in one place }\end{array}$ \\
\hline \begin{tabular}{|l|} 
Appealing \\
themes \\
\end{tabular} & $\begin{array}{l}\text { quality, innovation, } \\
\text { integration, success }\end{array}$ & $\begin{array}{l}\text { security, partnership, } \\
\text { growth }\end{array}$ & $\begin{array}{l}\text { quality, change, security, } \\
\text { integration }\end{array}$ \\
\hline Tonality & $\begin{array}{l}\text { seamless interplay; faster } \\
\text { decisions; an open dialogue; a } \\
\text { better integration }\end{array}$ & $\begin{array}{l}\text { healthier, easier life; } \\
\text { excited }\end{array}$ & $\begin{array}{l}\text { the right message to the } \\
\text { right people; } \\
\text { rocketing performance }\end{array}$ \\
\hline $\begin{array}{l}\text { Time and } \\
\text { space }\end{array}$ & now and across the company & on the fly & 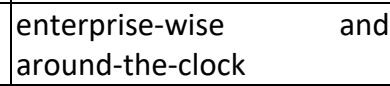 \\
\hline $\begin{array}{l}\text { Audio-visual } \\
\text { techniques: } \\
\text { music, voice } \\
\end{array}$ & $\begin{array}{l}\text { invigorating music, male and } \\
\text { female speakers }\end{array}$ & $\begin{array}{l}\text { invigorating music, only } \\
\text { male speaker }\end{array}$ & $\begin{array}{l}\text { invigorating music, male } \\
\text { and female speakers }\end{array}$ \\
\hline $\begin{array}{l}\text { Audio-visual } \\
\text { techniques: } \\
\text { setting and } \\
\text { salience } \\
\end{array}$ & $\begin{array}{l}\text { working and office settings, } \\
\text { happy customers, people } \\
\text { browsing through infographics, } \\
\text { planes at take-off }\end{array}$ & $\begin{array}{l}\text { working and office } \\
\text { settings, infographics, } \\
\text { organic food }\end{array}$ & $\begin{array}{l}\text { working and office settings, } \\
\text { through infographics, } \\
\text { bottles of sauce }\end{array}$ \\
\hline
\end{tabular}

\footnotetext{
${ }^{9}$ URL: https://www.youtube.com/watch?v=PXuDYk8QDH0

${ }^{10}$ URL: https://www.microsoft.com/en-us/microsoft-365/business

${ }^{11}$ URL: https://www.microsoft.com/en-us/microsoft-365/business
} 
Table 4 gives the details of analyzing Oracle customer testimonial videos, with the customers providing testimony on themes, such as: speed, flexibility, security, saving, etc. Similarly to that of the Microsoft client testimonials, the composition focuses on company information and settings, challenges, and - eventuallysolutions in order to create a similar antithesis of the prior and current situations culminating in the positive tonality of better, leading, faster, etc. experience:

Table 4

Analysis of Oracle customer testimonial videos

\begin{tabular}{|c|c|c|c|}
\hline Video & $\begin{array}{l}\text { Oracle customer testimonial } \\
\text { video } 1^{12} \text {. Duration 03:11 }\end{array}$ & $\begin{array}{l}\text { Oracle customer } \\
\text { testimonial video } 2^{13} \text {. } \\
\text { Duration } 01: 14\end{array}$ & $\begin{array}{l}\text { Oracle customer } \\
\text { testimonial video } 3^{14} \text {. } \\
\text { Duration 01:00 }\end{array}$ \\
\hline Company & Allianz & FireEye Cyber Security & CARE \\
\hline Composition & $\begin{array}{l}\text { 1) company information: } \\
\text { leading financial services } \\
\text { provider } \\
\text { 2) challenges: consolidate } \\
\text { data management, work } \\
\text { faster, reduce costs } \\
\text { 3) solutions: they are } \\
\text { faster and on-premise, } \\
\text { they've overcome all the } \\
\text { challenges } \\
\text { 4) future outlook: they can } \\
\text { achieve a higher maturity } \\
\text { level }\end{array}$ & $\begin{array}{l}\text { 1) company information: } \\
\text { security solutions provider } \\
\text { 2) challenges: improve } \\
\text { performance, tens of } \\
\text { millions of emails } \\
\text { 3) solutions: they can save } \\
\text { costs } \\
\text { 4) future outlook: protect } \\
\text { their customers better }\end{array}$ & $\begin{array}{l}\text { 1) company information: } \\
\text { helping mothers and babies } \\
\text { 2) challenges: high } \\
\text { maternity mortality } \\
\text { 3) solutions: they have } \\
\text { accelerated organizational } \\
\text { change, helping people and } \\
\text { saving lives } \\
\text { 4) future outlook: to } \\
\text { succeed in making an } \\
\text { impact on lives }\end{array}$ \\
\hline Antithesis & $\begin{array}{l}\text { prior: problems with } \\
\text { migrating data } \\
\text { now: consolidated and fast, } \\
\text { less expensive, more flexible }\end{array}$ & $\begin{array}{l}\text { prior: lots of emails to scan } \\
\text { now: consolidated effort, } \\
\text { saved costs }\end{array}$ & $\begin{array}{l}\text { prior: maternity and infant } \\
\text { deaths, lost hope } \\
\text { now: fewer deaths, positive } \\
\text { transformation underway }\end{array}$ \\
\hline $\begin{array}{l}\text { Appealing } \\
\text { themes }\end{array}$ & $\begin{array}{l}\text { flexibility and elasticity, } \\
\text { speed }\end{array}$ & security, saving & $\begin{array}{l}\text { commitment, impact, } \\
\text { change }\end{array}$ \\
\hline Tonality & $\begin{array}{l}\text { faster, more elasticity; solid } \\
\text { experience; a real mission; a } \\
\text { lot of positive experience; an } \\
\text { exciting journey/path to the } \\
\text { positive }\end{array}$ & \begin{tabular}{|lr} 
leading technology; better \\
protected; & significant \\
improvement & \\
& \\
\end{tabular} & accelerating change \\
\hline $\begin{array}{l}\text { Time and } \\
\text { space }\end{array}$ & faster and on-premise & Quickly & anywhere \\
\hline $\begin{array}{l}\text { Audio-visual } \\
\text { techniques: } \\
\text { music, voice }\end{array}$ & $\begin{array}{l}\text { invigorating music, male } \\
\text { speaker }\end{array}$ & $\begin{array}{l}\text { invigorating music, only } \\
\text { male speakers }\end{array}$ & $\begin{array}{l}\text { invigorating music, female } \\
\text { speakers }\end{array}$ \\
\hline $\begin{array}{l}\text { Audio-visual } \\
\text { techniques: } \\
\text { setting and } \\
\text { salience }\end{array}$ & $\begin{array}{l}\text { working and office settings, } \\
\text { happy customers, people } \\
\text { browsing } \\
\text { infographics }\end{array}$ & $\begin{array}{l}\text { working and office settings, } \\
\text { through } \\
\text { organic food }\end{array}$ & $\begin{array}{l}\text { ethnic settings, } \\
\text { females and infants }\end{array}$ \\
\hline
\end{tabular}

\footnotetext{
${ }^{12}$ URL: https://www.youtube.com/watch?v=S12xJXw71AQ

${ }^{13}$ URL: https://www.youtube.com/watch? $\mathrm{v}=\mathrm{stWqDXh0TCc}$

${ }^{14}$ URL: https://www.oracle.com/customers/infrastructure/care/
} 
Table 5 illustrates the results of analyzing $S A P$ customer testimonial videos whereas the customers focus on growth and future as well as security, with the other elements of testimonials being very similar to those of Microsoft and Oracle outlined above:

Table 5

Analysis of SAP customer testimonial videos

\begin{tabular}{|c|c|c|c|}
\hline Video & $\begin{array}{l}\text { SAP customer testimonial } \\
\text { video } 1^{15} \text {. Duration } 3: 00\end{array}$ & $\begin{array}{l}\text { SAP customer testimonial video } \\
2^{16} \text {. Duration 05:50 }\end{array}$ & $\begin{array}{l}\text { SAP } \quad \text { customer } \\
\text { testimonial video } 3^{17} . \\
\text { Duration 01:00 }\end{array}$ \\
\hline Company & ISlide & Markgräflich Badisches Weinhaus & Devialet \\
\hline Composition & $\begin{array}{l}\text { 1) company information: } \\
\text { customised slide producer } \\
\text { 2) challenges: keep all the } \\
\text { data in one place, manual } \\
\text { reporting } \\
\text { 3) solutions: they have } \\
\text { achieved the growth they } \\
\text { need } \\
\text { 4) future outlook: they } \\
\text { are excited about the future }\end{array}$ & $\begin{array}{l}\text { 1) company information: } \\
\text { German wine maker } \\
\text { 2) challenges: collect data, } \\
\text { convert the business into a viable } \\
\text { structure for the future } \\
\text { 3) solutions: they can collect } \\
\text { data from all the sensors in the } \\
\text { vineyard to send it to the cloud } \\
\text { 4) future outlook: protect the } \\
\text { data in real time, help decision } \\
\text { making for the future }\end{array}$ & $\begin{array}{l}\text { 1) company } \\
\text { information: best } \\
\text { sound provider } \\
\text { 2) challenges: growth } \\
\text { 3) solutions: manage } \\
\text { distribution, supply } \\
\text { chain } \\
\text { 4) future outlook: } \\
\text { grow in the business }\end{array}$ \\
\hline Antithesis & $\begin{array}{l}\text { prior: problems with } \\
\text { reporting and handling } \\
\text { data, no communication } \\
\text { now: integrated, increased } \\
\text { communication effort }\end{array}$ & $\begin{array}{l}\text { prior: lots of information to be } \\
\text { collected from sensors } \\
\text { now: just one laptop to get } \\
\text { information from all the sensors }\end{array}$ & $\begin{array}{l}\text { prior: } \\
\text { challenges } \\
\text { now: focused on the } \\
\text { data }\end{array}$ \\
\hline $\begin{array}{l}\text { Appealing } \\
\text { themes }\end{array}$ & vision, growth, efficiency & $\begin{array}{l}\text { benefit, decision-making, } \\
\text { security, future }\end{array}$ & \\
\hline Tonality & $\begin{array}{l}\text { happy, extremely excited; } \\
\text { comfortable; personal } \\
\text { touch; a huge part of their } \\
\text { growth }\end{array}$ & $\begin{array}{l}\text { revolutionize; easy, amazing; } \\
\text { competitive edge; proud, excited; } \\
\text { magic; an easier process; a fully- } \\
\text { blown system; a more superior } \\
\text { product }\end{array}$ & $\begin{array}{l}\text { best; a fast-growing } \\
\text { company; new ways; } \\
\text { confident }\end{array}$ \\
\hline $\begin{array}{l}\text { Time and } \\
\text { space }\end{array}$ & $\begin{array}{l}\text { fast and on-premise, } \\
\text { focused on the future }\end{array}$ & real-time and on-premise & anywhere \\
\hline $\begin{array}{l}\text { Audio-visual } \\
\text { techniques: } \\
\text { music, voice }\end{array}$ & $\begin{array}{l}\text { invigorating music, male } \\
\text { speakers }\end{array}$ & $\begin{array}{l}\text { invigorating music, female and } \\
\text { male speakers }\end{array}$ & $\begin{array}{l}\text { invigorating } \\
\text { male speaker }\end{array}$ \\
\hline $\begin{array}{l}\text { Audio-visual } \\
\text { techniques: } \\
\text { setting and } \\
\text { salience }\end{array}$ & working and office settings & $\begin{array}{l}\text { working and office settings, } \\
\text { through infographics, vineyards }\end{array}$ & $\begin{array}{l}\text { sound equipment } \\
\text { dancing people }\end{array}$ \\
\hline
\end{tabular}

${ }^{15}$ URL: https://www.youtube.com/watch?v=c1 sIELDwMuQ

${ }^{16}$ URL: https://news.sap.com/2018/09/blending-tradition-technology-markgraflichbadisches-weinhaus/

${ }^{17}$ URL: https://www.youtube.com/watch?v=LDiTMFyslAs 
As can be seen from the tables above, despite some differences, all the customers of Microsoft, Oracle, and SAP are very likely to focus on very similar themes, or lines of appeal, such as growth, success, future, security, etc. Thus, the audio-visual part of the multimodal discourse in the form of customer testimonial videos delivers some experience of a particular company while heavily relying on the same antitheses as previously employed in the marketing discourse of the locutionary sources.

\section{Conclusion}

Ultimately, this paper has attempted to gain insight into the multimodal marketing content of the Microsoft, Oracle, and SAP websites using the integrated approach which incorporates the assumptions of pragmatics, multimodal discourse analysis, and text linguistics in a search for a more comprehensive understanding of how the verbal and audio-visual means of the websites work together to deliver the ideologemes of the IT marketing discourse.

Since it is the intention that is behind the positive marketing discourse of IT under investigation, the discourses delivered by the vendors and the customers can be different. The vendors encourage and urge their clients to try the benefits of the IT-powered performance in the predominantly imperative discourse while the existing customers share their appealing stories of success achieved through the use of the solutions focusing on lines of appeal such as positive change, growth, success, quality, security, speed, integration, saving, etc. Nevertheless, it is the global persuasive intention of the software vendors that is dominant in constructing and delivering the overall marketing discourse.

It is of particular interest that all the three marketing discourses of Microsoft, Oracle, and $S A P$ as well as their textual and audio-visual customer testimonials make use of very similar antitheses juxtaposing multiple data vs. one solution and previously vs. now, implying old vs. new, slowly vs. fast, inefficiently vs. efficiently, etc.

The manifestation of IT themes, positive tonality, time and space is also very typical in all the three Microsoft, Oracle, and SAP discourses making the most of words such as insight(s), data, streamline, enhance, easi(ly), quick(ly), now, across, enterprise-wide, etc. and demonstrating some striking differences only when it comes to metaphors yielding some company-specific appeal, for example, don't drown in paperwork in the Microsoft discourse; jump on opportunities on the SAP website; or absorbing data in the Oracle context, etc.

The multimodal messages from the customer testimonial videos tend to focus more on the metaphorically and positively laden ideas of the IT solutions helping the inspired customers to feel the positive enterprise-wide change they have desperately aspired to before while the audio-visual techniques such as invigorating music and specific company settings are very typical.

Through the synergy of verbal and nonverbal means, the overall marketing discourse of Microsoft, Oracle, and SAP employs juxtapositions to render 
the global, all-pervasive and persuasive ideologeme of a more efficient IT-powered performance, with the resulting benefits being fully embraced by customers.

(C) Natalia Sokolova, 2020 cc)creative

This work is licensed under a Creative Commons Attribution 4.0 International License https://creativecommons.org/licenses/by/4.0/

\section{REFERENCES}

Abbamonte, Lucia \& Flavia Cavaliere. 2017. Shopping as 'best practice' — analyzing Walmart's debated sustainability policies. Russian Journal of Linguistics 21 (1). $105-125$.

Adebeshin, Keji. 2015. Explosing Symbolism in Masstige Brand Advertising within the Discursive Context of Luxury: A Semiotic Analysis. Dissertation. Auckland University.

Bateman, John. 2014. Text and Image: A Critical Introduction to the Visual/Verbal Divide. London and New York: Routledge.

Borisova, Evgeniya G. 2016. Marketingovaya lingvistika: napravleniya i perspektivy [Marketing linguistics: directions and prospects]. Verhnevolzhski philological bulletin 4. $140-143$.

Borisova, Evgeniya G., Larias G. Vikulova \& Lyubov' G. Antonova. 2019. Marketingovaya Lingvistika. Zakonomernosti Prodvigayushchego Teksta [Marketing Linguistics. Promotional text patterns]. Moscow: Flinta.

Caruana, Robert \& Andrew Crane. 2011. Getting away from it all: Exploring freedom in tourism. Annals of Tourism Research 34 (4). 1495-1515.

Caruana, Robert \& James Fitchett. 2015. Exploring the role of discourse in marketing and consumer research. Journal of Consumer Behaviour 14 (1). 1-12. DOI: 10.1002/cb.1497.

Dale, Robert. 2017. The commercial NLP landscape in 2017. Natural Language Engineering 23 (4). 641-647. [Electronic resource]. URL: https://doi.org/10.1017/ S1351324917000237. (Accessed 02 November 2019).

Dyer, Gillian. 1988. Advertising as Communication. London and New York: Routledge.

Fairclough, Norman. 2003. Analysing Discourse: Textual Analysis for Social Research. London and New York: Routledge.

Kibrik, Andrei. A. 2009. Modus, zanr i parametry klassifikacii diskursov [Modus, genre and other parameters of discourse classification]. Voprosy Yazykoznanyja 2. 3-21. (In Russ.).

Klushina, Natalia I. 2012. Intentsional'nyi metod v sovremennoi lingvisticheskoi paradigm [Intentional Method in the Modern Linguistic Paradigm]. Mediastilistika 4. [Electronic resource]. URL: http://mediascope.ru/node/1242. (Accessed 01 November 2019).

Klushina, Natalia I. 2016. Diskurs-analiz i stilistika: integrativnye metody issledovaniya media kommunikatsii [Discourse Analysis and Stylistics: Integrative Methods for Research of Media Communication]. Russian Journal of Linguistics 20 (4). 78-90. (In Russ.).

Kozhina, Margarita N. 2006. Stilisticheskii Entsiklopedicheskii Slovar' Russkogo Yazyka [Stylistic encyclopedic dictionary of the Russian language]. In Margarita Kozhina (eds.), Moscow: Flinta, Nauka Publ.

Kress, Gunther. 2010. Multimodality. London and New York: Routledge. 
Kress, Gunther \& Theo Van Leeuwen. 2001. Multimodal Discourse. London: Arnold.

Lemke, Jay. 1998. Multiplying meaning: Visual and verbal semiotics in scientific text. In Jim Martin \& Robert Veel (eds.), Reading science: Critical and functional perspectives on discourses of science, 87-113. London: Routledge.

Matveeva, Tatiana V. 2006a. Tekstovaya kategoriya [Text category]. In Margarita Kozhina (eds.), Stilisticheskii entsiklopedicheskii slovar' russkogo yazyka, 533-536. Moscow: Flinta, Nauka Publ.

Matveeva, Tatiana V. 2006b. Tema [Theme]. In Margarita Kozhina (eds.), Stilisticheskii entsiklopedicheskii slovar' russkogo yazyka, 542-544. Moscow: Flinta, Nauka Publ.

Matveeva, Tatiana V. 2006c. Tonal'nost' [Tonality]. In Margarita Kozhina (eds.), Stilisticheskii entsiklopedicheskii slovar' russkogo yazyka, 549-552. Moscow: Flinta, Nauka Publ.

Mooney, Annabelle. 2019. A fool and his money are soon parted: A critical examination of credit card websites. Russian Journal of Linguistics 23 (3). 642-658. DOI: 10.22363/ 2312-9182-2019-23-3-642-658.

Opgenhaffen, Michael. 2011. Multimedia, interactive and hypertextual features in divergent online news platforms: An exploratory study of Flemish online news. First Monday Journal 16 (3). [Electronic resource]. URL: http://firstmonday.org/ojs/index.php/fm/ article/view/2826/2814 (Accessed 02 November 2019).

Pirogova, Yulia. K. \& Pavel B. Parshin. 2000. Reklamnyi Tekst: Semiotika i Lingvistika [Promotional text: semiotics and linguistics]. Moscow: International Institute of Advertising, Grevennikov Publishing House.

Popova, Elena S. 2005. Reklamnyi Tekst i Problemy Manipulyatsii [Advertizing text and problem of manipulation]. Dissertation. Ekaterinburg.

Roper, Stuart, Robert Caruana, Dominic Medway \& Phil Murphy. 2013. Constructing luxury brands: Exploring the role of consumer discourse. European Journal of Marketing 47 (3 - 4). 375 - 400. DOI: 10.1108/03090561311297382.

Savelyeva, Irina P. \& Antonina I. Ukhova. 2015. Formirovanie Kompleksa Marketingovykh Kommunikatsii na Rynke Zhiloi Nedvizhimosti [Formation of Marketing Communications Complex in the Primary Residential Real Estate Market]. South-Urals State University.

Shchipitsyna, Larisa. Yu. 2009. Zhanry Komp'yuterno-Oposredovannoi Kommunikatsii [Genres of computer-mediated communication]. Monograph. Arkhangelsk: Pomor University.

Serrano, María José. 2018. The construction of advertising discourse by the use of the secondperson object Te and the clitic Se. Sociocultural Pragmatics: An International Journal of Spanish Linguistics 2. 173-196. [Electronic resource]. URL: https://www.degruyter.com/ downloadpdf/j/soprag.2018.6.issue-2/soprag-2018-0005/soprag-2018-0005.pdf. (Accessed 02 November 2019).

Van Leeuwen, Theo. 2013. Colour schemes. In Margit Boeck \& Norbert Pachler (eds.), Multimodality and social semiosis: Communication, meaning-making, and learning in the work of Gunther Kress. London: Routledge.

\section{Article history:}

Received: 17 March 2020

Revised: 08 April 2020

Accepted: 15 April 2020

\section{История статьи:}

Дата поступления в редакцию: 17 марта 2020

Дата принятия к печати: 15 апреля 2020 


\section{Bionote:}

NATALIA N. SOKOLOVA PhD, Associate Professor at Perm National Research Polytechnic University (Department of Foreign Languages, Linguistics, and Translation). Research interests: Critical discourse analysis, marketing linguistics, sociolinguistics, text linguistics, terminology, natural language processing tools.

\section{Contact information:}

Perm National Research Polytechnic University

29 Komsomolsky Prospekt, Perm, Perm Territory, 614990, Russia

e-mail:ntlk0@mail.ru

SPIN-RSCI: 2391-7440

ORCID ID: 0000-0003-0550-2272

Researcher ID: K-4038-2018

\section{СВЕДЕНИЯ ОБ АВТОРЕ:}

НАТАЛЬЯ ВЛАДИМИРОВНА СОКОЛОВА - кандидат филологических наук, доцент Пермского национального исследовательского политехнического университета (кафедра иностранных языков, лингвистики и перевода). Сфера научных интересов: критический анализ дискурса, маркетинговая лингвистика, социолингвистика, лингвистика текста, терминология, инструменты обработки естественных языков.

\section{Контактная информация:}

Пермский национальный исследовательский политехнический университет 614990, Россия, Пермский край, г. Пермь, Комсомольский проспект, д. 29

e-mail:ntlk0@mail.ru

SPIN-RSCI: 2391-7440

ORCID ID: 0000-0003-0550-2272

Researcher ID: K-4038-2018 